\title{
Bacillus siamensis sp. nov., isolated from salted crab (poo-khem) in Thailand
}

\author{
Punnanee Sumpavapol, ${ }^{1}$ Linna Tongyonk, ${ }^{1}$ Somboon Tanasupawat, ${ }^{2}$ \\ Nipa Chokesajjawatee, ${ }^{3}$ Plearnpis Luxananil ${ }^{3}$ and Wonnop Visessanguan ${ }^{3}$
}

Correspondence
Somboon Tanasupawat
Somboon.T@chula.ac.th

The genus Bacillus is a large and heterogeneous collection of aerobic or facultative anaerobic, rod-shaped, endosporeforming bacteria that are widely distributed in the environment. At the time of writing, this genus includes more than 228 species (Euzéby, 2009) of which several species have been utilized for various industrial applications ranging from the synthesis of pharmaceuticals and chemicals to food production. Species of the genus Bacillus continue to be dominant organisms in microbial fermentations, especially those on the US Food and Drug Administration's generally regarded as safe (GRAS) list. The ability of different species to ferment over acid, neutral and alkaline $\mathrm{pH}$ ranges, combined with the presence of thermophiles in the genus, has led to the development of a variety of new commercial enzyme products with the

The GenBank/EMBL/DDBJ accession number for the 16S rRNA gene sequence of strain PD-A10 $10^{\top}$ is GQ281299.

A TLC plate showing the polar lipids for strain $\mathrm{PD}-\mathrm{A} 10^{\top}$ is available as a supplementary figure with the online version of this paper. desired temperature, $\mathrm{pH}$ activity and stability properties to address a variety of applications (Schallmey et al., 2004).

Poo-khem is a type of salted crab product sold in Thailand. It is commonly produced by mixing fresh water crab, either Somanniathelpusa sp. or Sesarma mederi, with salt (8$17 \%$ ) and allowing the mixture to ferment in an earthen jar for 1 day (Phithakpol et al., 1995). Due to its salty taste and characteristic aroma, poo-khem has been used as a condiment to enhance the taste of other foods. Though it is quite popular, no studies have been done to determine the spectrum of micro-organisms associated with the spontaneous fermentation of poo-khem. However, halophilic or halotolerant members of the genus Bacillus are likely to be the most prevalent species and to persist until the end of the fermentation, a situation similar to that found for other salted fishery products such as fish sauce and krill paste (Saisithi et al., 1966; Crisan \& Sands, 1975; Yoon et al., 2001; Noguchi et al., 2004). In this study, a Gram-positive, rod-shaped bacterium, strain $\mathrm{PD}-\mathrm{A} 10^{\mathrm{T}}$, isolated from pookhem, was characterized by means of a polyphasic taxonomic approach and compared with other recognized 
species. Strain PD-A10 ${ }^{\mathrm{T}}$ exhibited characteristics that were sufficiently different from those of other recognized species of endospore-forming rods to distinguish it as a novel species of the genus Bacillus.

Strain PD-A $10^{\mathrm{T}}$ was isolated by means of a standard dilution plating technique from salted crab (poo-kem) collected from a local market in Nakornpathom Province, Thailand. The sample was plated on agar plates of modified Luria-Bertani (MLB) medium consisting of $1 \%(\mathrm{w} / \mathrm{v})$ tryptone, $0.5 \%(\mathrm{w} / \mathrm{v})$ yeast extract, $2.5 \%(\mathrm{w} / \mathrm{v})$ glucose, $5.0 \%(\mathrm{w} / \mathrm{v}) \mathrm{NaCl}$ and $1.5 \%(\mathrm{w} / \mathrm{v})$ agar $(\mathrm{pH} 7.2)(\mathrm{Kim}$ et al., 1997) and was incubated at $37{ }^{\circ} \mathrm{C}$ for $24 \mathrm{~h}$. A pure culture was obtained by repeated transfers of separate colonies on agar plates of the same medium. The reference strains used were Bacillus amyloliquefaciens KCTC $1660^{\mathrm{T}}$, B. subtilis subsp. subtilis KCTC $3135^{\mathrm{T}}$, B. vallismortis KCTC $3707^{\mathrm{T}}$, B. licheniformis KCTC $1918^{\mathrm{T}}$, B. mojavensis KCTC $3706^{\mathrm{T}}$ and $B$. velezensis KCTC $13012^{\mathrm{T}}$. Unless otherwise stated, strains were grown in MLB medium and cultivated at $37^{\circ} \mathrm{C}$ for $24 \mathrm{~h}$.

Morphological, cultural, physiological and biochemical characteristics were determined as described by Claus \& Berkeley (1986) and Barrow \& Feltham (1993) unless otherwise indicated. Colonies grown on trypticase soy agar (TSA) were examined for their morphological and cultural characteristics including cell shape, colonial appearance, endospore formation and pigmentation after incubation at $37{ }^{\circ} \mathrm{C}$ for 2 days. The Gram reaction was determined by the method of Hucker \& Conn (1923). Flagella were examined by using the staining method described by Rhodes (1958). Growth was tested on MacConkey agar and bile salt medium. Anaerobic growth was tested by incubating cultures on TSA plates with and without nitrate in an anaerobic jar with Anaerocult (Merck). Tests for catalase, oxidase, the hydrolysis of casein, aesculin, gelatin, starch, Tween 80 and tyrosine, DNase and urease activities, the methyl red/Voges-Proskauer (MR-VP) reaction, reduction of nitrate, phenylalanine deaminase activity and utilization of citrate were performed. $\mathrm{H}_{2} \mathrm{~S}$ production, indole production and cell motility were examined using sulphide-indole-motility (SIM) medium (Barrow \& Feltham, 1993). Growth in various salt concentrations $(0-20 \% \mathrm{NaCl})$, at different $\mathrm{pH}$ values $(4-11)$ and at various temperatures $\left(4-60{ }^{\circ} \mathrm{C}\right)$ were tested in nutrient broth. All tests were carried out by incubating the cultures at $37{ }^{\circ} \mathrm{C}$, except for investigations into the effect of temperature upon growth. Acid production profiles from carbohydrates were obtained with the API $50 \mathrm{CH}$ system (bioMérieux) after growth in $50 \mathrm{CHB}$ medium as described by Logan \& Berkeley (1984). Tubes from the API $50 \mathrm{CH}$ gallery were also examined for gas bubbles. API 20 ZYM tests (bioMérieux) were performed according to the manufacturer's instructions.

Cell biomass for analyses of isoprenoid quinone composition and isomers of diaminopimelic acid in the cell wall was obtained from cultivation in TSB at $37^{\circ} \mathrm{C}$ and determined according to the methods of Komagata \& Suzuki (1987). Polar lipids were extracted from freezedried cells $(300 \mathrm{mg})$, separated by two-dimensional silicagel TLC and detected with appropriate detection reagents (Tindall, 1990a, b). Cellular fatty acid content was determined by fatty acid methyl ester analysis according to the standard protocol of the MIDI/Hewlett Packard Microbial Identification System (MIS; Sasser, 1990) at the Identification Service of the DSMZ (Braunschweig, Germany). Fatty acid content was compared to the fatty acid database in the Microbial Identification System, Sherlock version 4.5 (MIDI).

DNA was extracted and purified from whole cells by the phenol method of Saito \& Miura (1963). The DNA G + C content was determined by the method of Tamaoka \& Komagata (1984), with the modification that DNA was hydrolysed and the resultant nucleotides were analysed by reversed-phase HPLC. $16 \mathrm{~S}$ rRNA gene sequencing was carried out using the methods reported by Shida et al. (1996) and Takagi et al. (1993). The 16S rRNA gene was amplified by PCR with the universal bacterial primers, 16S27 F ( $5^{\prime}$-AGAGTTTGATCMTGGCTCAG-3') annealed at positions 8-27 and 16S-1539 R (5'-CCAGTGAGCAGAGTGACG-3') annealed at positions 1522-1539 (Escherichia coli numbering according to Brosius et al., 1978). The amplification reaction was performed with a volume of $25 \mu \mathrm{l}$, using the Takara Ex Taq DNA polymerase and buffer system (Takara Mirus Bio Corporation). The final PCR mixture comprised $1 \times E x$ Taq buffer (with $1.5 \mathrm{mM}$ $\mathrm{MgCl}_{2}$ ), $200 \mu \mathrm{M}$ of each deoxynucleoside triphosphate, $0.2 \mu \mathrm{M}$ of each primer, 1 unit Ex Taq DNA polymerase and 50 ng template DNA. Amplification was carried out in a thermocycler (GeneAmp PCR System 2400, PE Biosystems) with the following cycling program: initial denaturation at $94{ }^{\circ} \mathrm{C}$ for $5 \mathrm{~min}$ followed by 25 cycles of $94{ }^{\circ} \mathrm{C}$ for $10 \mathrm{~s}$, annealing at $58{ }^{\circ} \mathrm{C}$ for $30 \mathrm{~s}$, and extension at $72{ }^{\circ} \mathrm{C}$ for $2 \mathrm{~min}$, and a final extension step at $72{ }^{\circ} \mathrm{C}$ for $10 \mathrm{~min}$. The PCR product was purified using a QIAquickPCR purification kit (Qiagen). The double-stranded DNA was sequenced with an ABI PRISM BigDye Terminator v3.1 Cycle Sequencing kit (Applied Biosystems) according to the manufacturer's instructions, by the use of the following four primers; 16S-357 $\mathrm{R}$ (5'-CTGCTGCCTCCCGTAG- ${ }^{\prime}$ ) annealed at positions $342-357,16 S-802 \mathrm{R}$ (5'-TACCAGGGTATCTAATCC-3') annealed at positions 785-802, 16S-1115 R (5'-AGGGTTGCGCTCGTTG-3') annealed at positions $1000-1115$ and $16 \mathrm{~S}-1539 \mathrm{R}\left(5^{\prime}-\right.$ CCAGTGAGCAGAGTGACG-3') annealed at positions 1522-1539. The PCR products were sequenced with an ABI PRISM 377 Genetic Analyzer (Applied Biosystems). The 16S rRNA gene sequence obtained (1525 bases) was deposited in the GenBank/EMBL/DDBJ databases with accession no. GQ281299. The sequence was aligned along with selected sequences from the GenBank/EMBL/DDBJ databases by using the CLUSTAL_X program (version 1.81) (Thompson et al., 1997). Gaps and ambiguous bases were eliminated from the calculations. The distance matrices for 
the aligned sequences were calculated by the two-parameter method of Kimura (1980). A phylogenetic tree was constructed by the neighbour-joining method (Saitou \& Nei, 1987) with the MEGA program (version 2.1) (Kumar et al., 2001). The confidence values of individual branches in the phylogenetic tree were determined by using the bootstrap analysis of Felsenstein (1985) based on 1000 samplings. Repetitive sequence based PCR (rep-PCR) fingerprinting, as described by Versalovic et al. (1994), was carried out with $(\mathrm{GTG})_{5}$ primer (5'-GTGGTGGTGGTGGTG-3') (Gevers et al., 2001) and the PCR and electrophoresis conditions were modified from Chokesajjawatee et al. (2008). The amplification reaction was carried out in a volume of $50 \mu \mathrm{l}$ and the final PCR mixture comprised $1 \times E x$ Taq buffer (with $1.5 \mathrm{mM} \mathrm{MgCl}_{2}$ ), $200 \mu \mathrm{M}$ of each deoxynucleoside triphosphate, $800 \mathrm{nM}$ primer, 1.25 units Ex Taq DNA polymerase and $50 \mathrm{ng}$ template DNA. Amplification was carried out in a Peltier PTC-200 thermal cycler (MJ Research Inc.) with the following cycling program: initial denaturation at $95{ }^{\circ} \mathrm{C}$ for $5 \mathrm{~min}$ followed by 35 cycles of $94{ }^{\circ} \mathrm{C}$ for $45 \mathrm{~s}$, annealing at $40{ }^{\circ} \mathrm{C}$ for $1 \mathrm{~min}$, and extension at $65^{\circ} \mathrm{C}$ for $10 \mathrm{~min}$, and a final extension step at $65{ }^{\circ} \mathrm{C}$ for $20 \mathrm{~min}$. A $5 \mu \mathrm{l}$ aliquot of the PCR product was electrophoresed for $2.4 \mathrm{~h}$ at $4 \mathrm{~V} \mathrm{~cm}^{-1}$ on a $1 \%(\mathrm{w} / \mathrm{v})$ agarose gel in $0.5 \times \mathrm{TBE}$ buffer $(0.045 \mathrm{M}$ Tris base, $0.045 \mathrm{M}$ boric acid, $0.001 \mathrm{M}$ EDTA, pH 8.0). After staining with ethidium bromide $\left(0.5 \mu \mathrm{g} \mathrm{ml}^{-1}\right)$, the fingerprint patterns were captured using a laser scanner Typhoon 9410 (Amersham Pharmacia Biotech). The resulting fingerprints were analysed using the GelComparII v.4.5 computer package (Applied Maths). The similarities in the fingerprint patterns were calculated using the Pearson correlation coefficient and the cluster analysis was performed using the unweighted-pair group method using average linkages (UPGMA). The different dendrograms were interpreted visually to set the delineation level separately for each species. DNA-DNA hybridization was carried out by the photobiotin-labelling method with microdilution wells at $43{ }^{\circ} \mathrm{C}$ for $5 \mathrm{~h}$ (Ezaki et al., 1989).

Cells of strain PD-A $10^{\mathrm{T}}$ were Gram-positive, facultatively anaerobic, endospore-forming rods that were $0.3-0.6 \mu \mathrm{m}$ wide and $1.5-3.5 \mu \mathrm{m}$ long after $48 \mathrm{~h}$ culture on TSA. Colonies formed on agar plates were creamy white, mucoid, translucent, raised, had entire margins and were 3-4 mm in diameter after 2 days incubation at $37{ }^{\circ} \mathrm{C}$. In TSB, a thin film formed at the surface whilst the rest of the medium was uniformly cloudy. Strain PD-A $10^{\mathrm{T}}$ could be differentiated from other phylogenetically related species of the genus Bacillus by means of some phenotypic characteristics (Table 1). For example, strain $\mathrm{PD}-\mathrm{A} 10^{\mathrm{T}}$ was halo-acidotolerant and was able to grow at acidic $\mathrm{pH}$ values and in the presence of $\mathrm{NaCl}$ up to $14 \%(\mathrm{w} / \mathrm{v})$. In addition, strain $\mathrm{PD}-\mathrm{A} 10^{\mathrm{T}}$ was able to grow over a wider range of temperatures, especially at $55{ }^{\circ} \mathrm{C}$, when compared with related species.

Table 1. Differential characteristics of strain $\mathrm{PD}-\mathrm{A} 10^{\top}$ and related species of the genus Bacillus

Strains: 1 , PD-A $10^{\mathrm{T}} ; 2$, B. amyloliquefaciens $\mathrm{KCTC} 1660^{\mathrm{T}} ; 3$, B. subtilis subsp. subtilis $\mathrm{KCTC} 3135^{\mathrm{T}} ; 4$, B. vallismortis $\mathrm{KCTC}^{3707^{\mathrm{T}}}$; 5 , B. mojavensis KCTC $3706^{\mathrm{T}}$; 6, B. licheniformis KCTC $1918^{\mathrm{T}}$. Data were obtained in this study unless otherwise indicated. +, Positive; - , negative; ND, not determined.

\begin{tabular}{|c|c|c|c|c|c|c|}
\hline Characteristic & 1 & 2 & 3 & 4 & 5 & 6 \\
\hline Oxidase activity & - & + & + & + & + & + \\
\hline Citrate utilization & - & + & + & + & + & + \\
\hline \multicolumn{7}{|l|}{ Temperature for growth $\left({ }^{\circ} \mathrm{C}\right)$ : } \\
\hline Maximum & 55 & 50 & 50 & 50 & 50 & 55 \\
\hline Minimum & 4 & 10 & 10 & 10 & 10 & 15 \\
\hline \multicolumn{7}{|c|}{ Growth in the presence of $\mathrm{NaCl}(\%)$ : } \\
\hline Maximum & 14 & 10 & 12 & 10 & 12 & 10 \\
\hline \multicolumn{7}{|l|}{ Growth at $\mathrm{pH}$ : } \\
\hline Minimum & 4.5 & 6 & 6 & 6 & 5 & 6 \\
\hline \multicolumn{7}{|l|}{ Acid from: } \\
\hline D-Arabinose & - & + & + & + & ND & + \\
\hline Gentiobiose & + & - & - & - & - & - \\
\hline Glycogen & + & - & - & - & - & - \\
\hline Lactose & + & + & - & - & - & - \\
\hline Melibiose & - & + & + & - & - & + \\
\hline Methyl $\alpha$-D-glucoside & + & + & + & - & - & + \\
\hline Trehalose & - & + & + & + & + & + \\
\hline Turanose & - & - & + & - & - & + \\
\hline D-Xylose & + & - & - & - & + & - \\
\hline DNA G $+C$ content $(\mathrm{mol} \%)$ & 41.4 & $45.4^{a_{\star}}$ & $42.9^{b}$ & $43.7^{c}$ & $43.4^{d}$ & $45.3^{c}$ \\
\hline
\end{tabular}

${ }^{*}$ Data from: $a$, Priest et al. (1988); b, Claus \& Berkeley (1986); c, Roberts et al. (1996); d, Roberts et al. (1994). 
Strain PD-A $10^{\mathrm{T}}$ contained meso-diaminopimelic acid as the diagnostic diamino acid in the cell-wall peptidoglycan and had menaquinone with seven isoprene units (MK-7) as the predominant isoprenoid quinone. The cellular fatty acid profiles showed a large amount of branched fatty acids; the major components were anteiso- $\mathrm{C}_{15: 0}(42.35 \%)$ and anteiso- $\mathrm{C}_{17: 0}(22.65 \%)$ (Table 2). Cellular fatty acid profiles, particularly major fatty acid(s), distinguished strain $\mathrm{PD}-\mathrm{A} 10^{\mathrm{T}}$ from the closely related species in the genus Bacillus. The genus Bacillus comprises variable species having anteiso- $\mathrm{C}_{15: 0}$ and iso- $\mathrm{C}_{15: 0}$ as the major fatty acids (Shida et al., 1997 and Yoon et al., 2001). Accordingly, strain $\mathrm{PD}-\mathrm{A} 10^{\mathrm{T}}$ was distinct from some groups of species within the genus Bacillus. The DNA $\mathrm{G}+\mathrm{C}$ content of strain $\mathrm{PD}-\mathrm{A} 10^{\mathrm{T}}$ was $41.4 \mathrm{~mol} \%$. Diphosphatidylglycerol, phosphatidylglycerol, phosphatidylethanolamine, lysylphosphatidylglycerol, glycolipid, an unknown aminophospholipid, four unknown aminolipids and two unknown lipids were found (see Supplementary Fig. S1 in IJSEM Online).

An almost-complete 16S rRNA gene sequence of strain PD$\mathrm{A} 10^{\mathrm{T}}$ comprising $1525 \mathrm{nt}$ was determined directly after PCR amplification. In a phylogenetic tree based on $16 \mathrm{~S}$ rRNA gene sequences, strain PD-A $10^{\mathrm{T}}$ formed a cluster with Bacillus amyloliquefaciens NBRC $15535^{\mathrm{T}}$ within the genus Bacillus (Fig. 1). 16S rRNA gene sequence similarities between strain $\mathrm{PD}-\mathrm{A} 10^{\mathrm{T}}$ and B. amyloliquefaciens NBRC $15535^{\mathrm{T}}$, B. subtilis subsp. subtilis DSM $10^{\mathrm{T}}, B$. vallismortis DSM $11031^{\mathrm{T}}$ and B. mojavensis IFO $15718^{\mathrm{T}}$ were 99.5 , 99.4,

Table 2. Cellular fatty acid profiles (\%) of strain $\mathrm{PD}-\mathrm{A} 10^{\top}$ and related species of the genus Bacillus

Strains: 1, PD-A10 ${ }^{\mathrm{T}} ; 2$, B. amyloliquefaciens $\mathrm{KCTC} 1660^{\mathrm{T}} ; 3$, B. subtilis subsp. subtilis KCTC $3135^{\mathrm{T}} ; 4$, B. vallismortis KCTC $3707^{\mathrm{T}} ; 5, B$. mojavensis KCTC $3706^{\mathrm{T}}$; 6, B. licheniformis KCTC $1918^{\mathrm{T}}$. Data were obtained in this study by the Identification Service of the DSMZ (Braunschweig, Germany). The relative amount of each fatty acid is expressed as a percentage of the total fatty acid. -, Value below limit of detection.

\begin{tabular}{|c|c|c|c|c|c|c|}
\hline Fatty acid & 1 & 2 & 3 & 4 & 5 & 6 \\
\hline \multicolumn{7}{|c|}{ Straight-chain saturated } \\
\hline $\mathrm{C}_{14: 0}$ & 0.56 & 0.70 & - & - & - & 0.48 \\
\hline $\mathrm{C}_{16: 0}$ & 6.41 & 5.40 & 3.65 & 2.71 & 2.05 & 3.67 \\
\hline \multicolumn{7}{|c|}{ Branch-chain saturated } \\
\hline iso- $\mathrm{C}_{14: 0}$ & 1.42 & 1.48 & 0.87 & 1.07 & 0.98 & 0.87 \\
\hline iso- $\mathrm{C}_{15: 0}$ & 9.80 & 28.63 & 24.08 & 24.60 & 22.33 & 32.36 \\
\hline iso- $\mathrm{C}_{16: 0}$ & 6.47 & 3.12 & 2.47 & 4.06 & 2.56 & 3.74 \\
\hline iso- $\mathrm{C}_{17: 0}$ & 9.81 & 13.18 & 11.53 & 14.43 & 8.92 & 8.42 \\
\hline anteiso- $\mathrm{C}_{15: 0}$ & 42.35 & 33.10 & 38.48 & 37.50 & 42.51 & 34.08 \\
\hline anteiso- $\mathrm{C}_{17: 0}$ & 22.65 & 8.65 & 12.52 & 12.07 & 12.53 & 11.64 \\
\hline \multicolumn{7}{|c|}{ Monounsaturated } \\
\hline $\mathrm{C}_{16: 1} \omega 11 c$ & - & 2.73 & 1.75 & - & - & 1.43 \\
\hline iso- $\mathrm{C}_{17: 1} \omega 10 c$ & - & 2.05 & 2.41 & - & - & 1.47 \\
\hline
\end{tabular}

99.4 and $99.2 \%$, respectively. The relationship between strain $\mathrm{PD}-\mathrm{A} 10^{\mathrm{T}}$ and closely related species of the genus Bacillus was also determined by the rep-PCR fingerprinting method, a useful technique for determining inter- and intraspecies relatedness (Versalovic et al., 1994 and Gevers et al., 2001). The fingerprints obtained with primer (GTG) are shown in Fig. 2. The (GTG) $)_{5}$ PCR patterns resulted in the delineation of three (GTG) $)_{5}-\mathrm{PCR}$ clusters with Pearson's correlation coefficient values of $50.6 \%$, comprising four, two and one isolates. Within the clusters, the $(\mathrm{GTG})_{5}$ patterns showed delineation of the strains examined at Pearson's correlation coefficient values of 70 , 72.8 and $74 \%$ indicating that they were different genotypically and belonged to separate distinct species. Nick et al. (1999) and Rademaker et al. (2000) have compared rep-PCR genomic fingerprint analysis with DNA-DNA relatedness; they suggested that the two techniques yield results that are in close agreement. Heyrman et al. (2003) reported that rep-PCR fingerprinting can be used as a genomic screening method to differentiate strains at the species level and to select representatives for DNA-DNA reassociation experiments. A DNA-DNA hybridization study revealed that strain PD$\mathrm{A} 10^{\mathrm{T}}$ showed only low levels of DNA-DNA relatedness to B. amyloliquefaciens KCTC $1660^{\mathrm{T}}(39.46 \%)$, B. vallismortis KCTC $3707^{\mathrm{T}}(27.43 \%)$ and B. subtilis subsp. subtilis KCTC $3135^{\mathrm{T}}(25.34 \%)$ as shown in Table 3. Thus, strain PD-A10 is not a member of these recognized species of the genus Bacillus.

In conclusion, on the basis of the above physiological and biochemical data, molecular phylogenetic results, cellular fatty acid compositions and DNA G $+\mathrm{C}$ content, strain $\mathrm{PD}-\mathrm{A} 10^{\mathrm{T}}$ represents a novel species of the genus Bacillus, for which the name Bacillus siamensis sp. nov. is proposed.

\section{Description of Bacillus siamensis sp. nov.}

Bacillus siamensis (si.am.en'sis. N.L. masc. adj. siamensis pertaining to Siam, the old name of Thailand, from where the type strain was isolated).

Cells are Gram-positive, facultatively anaerobic and rodshaped, measuring $0.3-0.6 \times 1.5-3.5 \mu \mathrm{m}$. Cells occur singly, in pairs and occasionally in short chains. They are motile with peritrichous flagella. Ellipsoidal endospores are produced at central or subterminal positions in swollen sporangia. Colonies are creamy white, mucoid, translucent, raised, have an entire margin and are 3-4 mm in diameter after 2 days incubation at $37^{\circ} \mathrm{C}$ on TSA. In liquid medium, a thin film is formed at the surface whilst the rest of the medium is uniformly cloudy. Anaerobic growth occurs. Grows on MacConkey agar but not on bile salt medium. Produces catalase but not oxidase. Positive result in tests for the hydrolysis of casein, aesculin, gelatin, DNA and starch, for nitrate reduction and with the Voges-Proskauer test. Negative results in tests for hydrolysis of tyrosine and Tween 80 , production of $\mathrm{H}_{2} \mathrm{~S}$ and indole, urease activity 


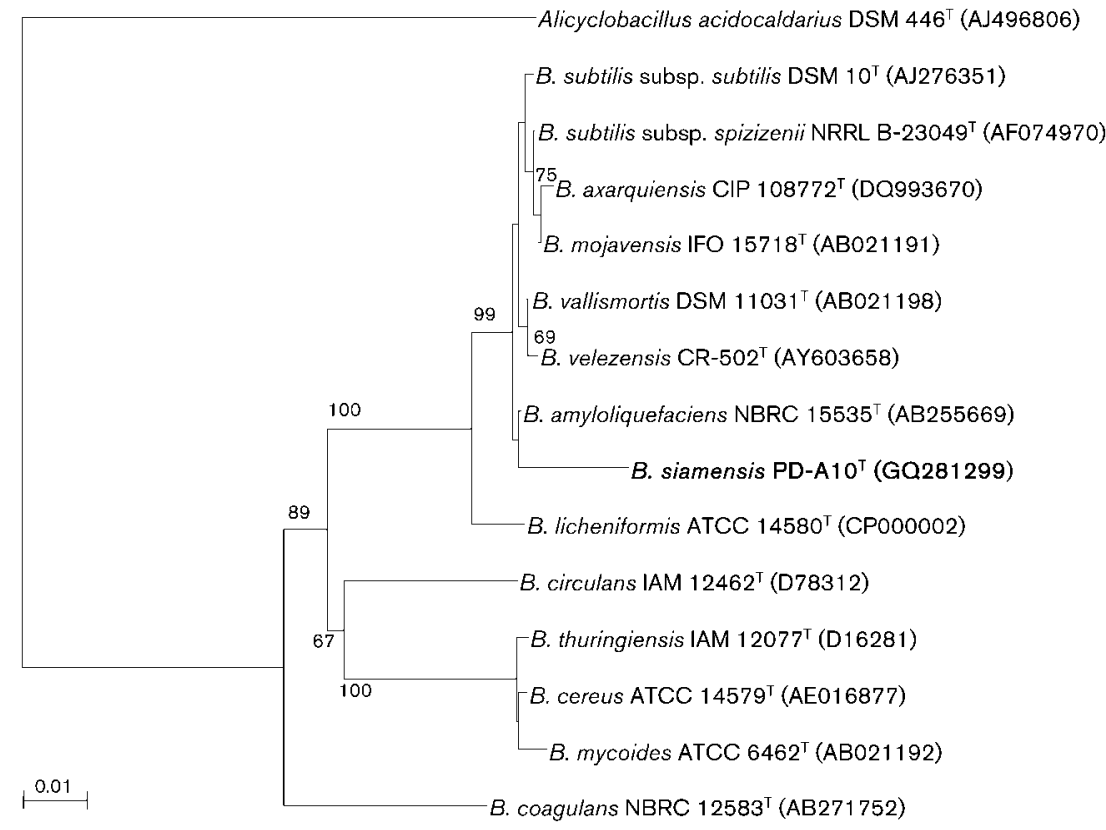

Fig. 1. Phylogenetic relationships of strain PD-A10 ${ }^{\top}$, some species of the genus Bacillus and related taxa based on $16 \mathrm{~S}$ rRNA gene sequence analysis. The branching pattern was generated by the neighbour-joining method. Bootstrap values (expressed as percentages of 1000 replications) $>60 \%$ are shown at the branch points. Bar, 0.01 substitutions per nucleotide position. and the methyl-red reaction. Growth occurs at $4{ }^{\circ} \mathrm{C}$ and $55{ }^{\circ} \mathrm{C}$; optimal growth temperature is $37{ }^{\circ} \mathrm{C}$. Growth occurs between $\mathrm{pH} 4.5$ and 9.0 and the optimal $\mathrm{pH}$ is 67. Growth occurs in the presence of $0-14 \%(w / v) ~ N a C l$ and optimally with no $\mathrm{NaCl}$. Phenylalanine and tryptophan deaminase are not produced. When assayed with the API ZYM system, alkaline phosphatase, esterase (C4), esterase lipase (C8) and naphthol-AS-BI-phosphohydrolase are present, but lipase (C14), leucine arylamidase, valine arylamidase, cystine arylamidase, trypsin, $\alpha$-chymotrypsin, acid phosphatase, $\alpha$-galactosidase, $\beta$-galactosidase, $\alpha$-glucosidase, $\beta$-glucosidase, $\beta$-glucuronidase, $N$-acetyl- $\beta$-glucosaminidase, $\alpha$-mannosidase and $\alpha$-fucosidase are absent. Acid is produced from glycerol, L-arabinose, D-ribose,
D-xylose, D-glucose, D-fructose, inositol, D-mannitol, Dsorbitol, methyl $\alpha$-D-glucopyranoside, amygdalin, arbutin, aesculin ferric citrate, salicin, cellobiose, maltose, lactose, sucrose, raffinose, starch, glycogen and gentiobiose. Acid is not produced from erythritol, D-arabinose, L-xylose, $\mathrm{D}$-adonitol, methyl $\beta$-D-xylopyranoside, D-galactose, $\mathrm{D}$ mannose, L-sorbose, L-rhamnose, dulcitol, methyl $\alpha$-Dmannopyranoside, $\mathrm{N}$-acetylglucosamine, trehalose, inulin, melezitose, xylitol, turanose, D-lyxose, D-tagatose, D-fucose, L-fucose, D-arabitol, L-arabitol, potassium gluconate, potassium 2-ketogluconate or potassium 5-ketogluconate. The cell-wall peptidoglycan contains meso-diaminopimelic acid. The predominant menaquinone is MK-7. The major fatty acids are anteiso- $C_{15: 0}$, anteiso- $C_{17: 0}$, iso- $C_{17: 0}$ and

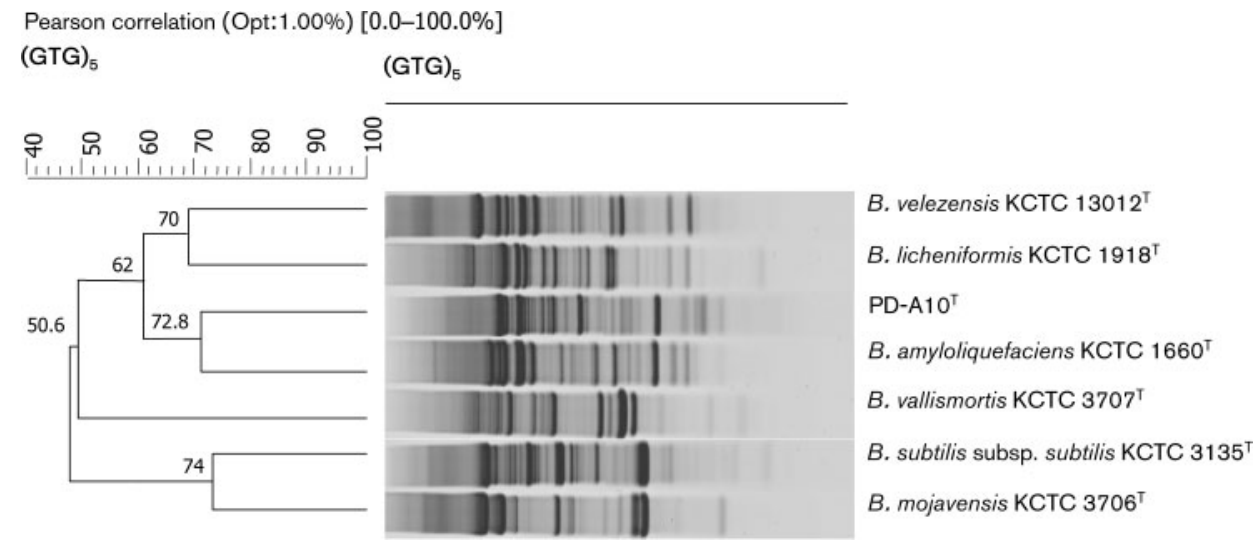

Fig. 2. (GTG $)_{5}-P C R$ banding patterns of strain $P D-A 10^{\top}$ and related species of the genus Bacillus. The dendrogram was generated after cluster analysis of the digitized fingerprints and was derived from UPGMA linkage of Pearson's correlation similarity coefficients. 
Table 3. DNA-DNA relatedness of strain PD-A10 $0^{\top}$ and related species of the genus Bacillus

ND, Not determined.

\begin{tabular}{|c|c|c|c|}
\hline \multirow[t]{2}{*}{ Strain } & \multicolumn{3}{|c|}{$\%$ DNA-DNA reassociation with ${ }^{\star}$} \\
\hline & 1 & 2 & 3 \\
\hline 2. B. amyloliquefaciens KCTC $1660^{\mathrm{T}}$ & 39.46 & 100 & $\mathrm{ND}$ \\
\hline 3. B. subtilis subsp. subtilis KCTC $3135^{\mathrm{T}}$ & 25.34 & ND & 100 \\
\hline B. vallismortis KCTC $3707^{\mathrm{T}}$ & 27.43 & ND & ND \\
\hline
\end{tabular}

${ }^{*}$ Means of the values from three determinations.

iso- $\mathrm{C}_{15: 0}$. The polar lipids are diphosphatidylglycerol, phosphatidylglycerol, phosphatidylethanolamine, lysylphosphatidylglycerol, glycolipid, an unknown aminophospholipid, four unknown aminolipids and two unknown lipids.

The type strain, PD-A $10^{\mathrm{T}}\left(=\mathrm{BCC} 22614^{\mathrm{T}}=\mathrm{KCTC} 13613^{\mathrm{T}}\right)$, was isolated from salted crab (poo-khem). The DNA G $+\mathrm{C}$ content of the type strain is $41.4 \mathrm{~mol} \%$.

\section{Acknowledgements}

This study was supported by a Faculty of Pharmaceutical Sciences Research Fund, Chulalongkorn University (2007), a grant from Thailand Graduate Institute of Science and Technology (TGIST), National Science and Technology Development Agency (NSTDA) (2006-2008) and in part supported by Graduate School, Chulalongkorn University (2008). The authors thank Professor Viroj Wiwanitkit, Wiwanit House, Bangkhae, Bangkok, for his comments on the correct wording for the food sample from which the novel strain was isolated.

\section{References}

Barrow, G. I. \& Feltham, R. K. A. (1993). Cowan and Steel's Manual for the Identification of Medical Bacteria, 3rd edn. Cambridge: Cambridge University Press.

Brosius, J., Palmer, M. L., Kennedy, P. J. \& Noller, H. F. (1978). Complete nucleotide sequence of a $16 \mathrm{~S}$ ribosomal RNA gene from Escherichia coli. Proc Natl Acad Sci U S A 75, 4801-4805.

Chokesajjawatee, N., Zo, Y. G. \& Colwell, R. R. (2008). Determination of clonality and relatedness of Vibrio cholerae isolates by genomic fingerprinting, using long-range repetitive element sequence-based PCR. Appl Environ Microbiol 74, 5392-5401.

Claus, D. \& Berkeley, R. C. W. (1986). Genus Bacillus Cohn $1872^{174 \mathrm{AL}}$. In Bergey's Manual of Systematic Bacteriology, vol. 2, pp. 1105-1139. Edited by P. H. A. Sneath, N. S. Mair, M. E. Sharpe \& J. G. Holt. Baltimore: Williams \& Wilkins.

Crisan, E. V. \& Sands, A. (1975). Microflora of four fermented fish sauces. Appl Microbiol 29, 106-108.

Euzéby, J. P. (2009). List of bacterial names with standing in nomenclature: a folder available on the Internet. [Last full update 25 August 2009]. http://www.bacterio.net

Ezaki, T., Hashimoto, Y. \& Yabuuchi, E. (1989). Fluorometric deoxyribonucleic acid-deoxyribonucleic acid hybridization in microdilution wells as an alternative to membrane filter hybridization in which radioisotopes are used to determine genetic relatedness among bacterial strains. Int J Syst Bacteriol 39, 224-229.

Felsenstein, J. (1985). Confidence limits on phylogenies: an approach using the bootstrap. Evolution 39, 783-791.

Gevers, D., Huys, G. \& And Swings, J. (2001). Applicability of repPCR fingerprinting for identification of Lactobacillus species. FEMS Microbiol Lett 205, 31-36.

Heyrman, J., Balcaen, A., Rodriguez-Diaz, M., Logan, N. A., Swings, J. \& Vos, P. D. (2003). Bacillus decolorationis sp. nov., isolated from biodeteriorated parts of the mural paintings at the Servilia tomb (Roman necropolis of Carmona, Spain) and the SaintCatherine chapel (Castle Herberstein, Austria). Int J Syst Evol Microbiol 53, 459-463.

Hucker, G. L. \& Conn, H. J. (1923). Method of Gram staining. N $Y$ State Agric Exp Sta Tech Bull 93, 3-37.

Kim, H.-K., Kim, G.-T., Kim, D.-K., Choi, W.-A., Park, S.-H., Jeong, Y.-K. \& Kong, I.-S. (1997). Purification and characterization of a novel fibrinolytic enzyme from Bacillus sp. KA 38 originated from fermented fish. J Ferment Bioeng 84, 307-312.

Kimura, M. (1980). A simple method for estimating evolutionary rates of base substitutions through comparative studies of nucleotide sequences. J Mol Evol 16, 111-120.

Komagata, K. \& Suzuki, K. (1987). Lipid and cell-wall analysis in bacterial systematics. Methods Microbiol 19, 161-207.

Kumar, S., Tamura, K., Jakobson, I. B. \& Nei, M. (2001). MEGA 2: Molecular evolution analysis software. Bioinformatics 17, 1244-1245.

Logan, N. A. \& Berkeley, R. C. W. (1984). Identification of Bacillus strains using the API system. J Gen Microbiol 130, 1871-1882.

Nick, G., Jussila, M., Hoste, B., Niemi, R. M., Kaijalainen, S., de Lajudie, P., Gillis, M., de Bruijn, F. J. \& Lindström, K. (1999). Rhizobia isolated from root nodules of tropical leguminous trees characterized using DNA-DNA dot-blot hybridization and rep-PCR genomic fingerprinting. Syst Appl Microbiol 22, 287-299.

Noguchi, H., Uchino, M., Shida, O., Takano, K., Nakamura, L. K. \& Komagata, K. (2004). Bacillus vietnamensis sp. nov., a moderately halotolerant, aerobic, endospore-forming bacterium isolated from Vietnamese fish sauce. Int J Syst Evol Microbiol 54, 2117-2120.

Phithakpol, B., Varanyanond, W., Reungmaneepaitoon, S. \& Wood, H. (1995). The Traditional Fermented Foods of Thailand. Kuala Lumpur: ASEAN Food Handling Bureau Level 3.

Priest, F. G., Goodfellow, M. \& Todd, C. (1988). A numerical classification of the genus Bacillus. J Gen Microbiol 134, 1847-1882.

Rademaker, J. L. W., Hoste, B., Louws, F. J., Kersters, K., Swings, J., Vauterin, L., Vauterin, P. \& de Bruijn, F. J. (2000). Comparison of AFLP and rep-PCR genomic fingerprinting with DNA-DNA 
homology studies: Xanthomonas as a model system. Int J Syst Evol Microbiol 50, 665-677.

Rhodes, M. E. (1958). The cytology of Pseudomonas spp. as revealed by a silver-plating staining method. J Gen Microbiol 18, 639-648.

Roberts, M. S., Nakamura, L. K. \& Cohan, F. M. (1994). Bacillus mojavensis sp. nov., distinguishable from Bacillus subtilis by sexual isolation, divergence in DNA sequence, and differences in fatty acid composition. Int J Syst Bacteriol 44, 256-264.

Roberts, M. S., Nakamura, L. K. \& Cohan, F. M. (1996). Bacillus vallismortis sp. nov., a close relative of Bacillus subtilis isolated from soil in Death Valley, California. Int J Syst Bacteriol 46, 470-475.

Saisithi, P., Kasemsarn, R. O., Liston, J. \& Dollar, A. M. (1966). Microbiology and chemistry of fermented fish. J Food Sci 31, 105-110.

Saito, H. \& Miura, K. (1963). Preparation of transforming deoxyribonucleic acid by phenol treatment. Biochim Biophys Acta 72, 619-629.

Saitou, N. \& Nei, M. (1987). The neighbor-joining method: a new method for reconstructing phylogenetic trees. Mol Biol Evol 4, 406-425.

Sasser, M. (1990). Identification of Bacteria by Gas Chromatography of Cellular Fatty Acids. MIDI Technical Note 101. Newark, DE, USA: Microbial ID, Inc.

Schallmey, M., Singh, A. \& Ward, O. P. (2004). Developments in the use of Bacillus species for industrial production. Can J Microbiol 50, 1-17.

Shida, O., Takagi, H., Kadowaki, K. \& Komagata, K. (1996). Proposal for two new genera, Brevibacillus gen. nov. and Aneurinibacillus gen. nov. Int J Syst Bacteriol 46, 939-946.

Shida, O., Takagi, H., Kadowaki, K., Nakamura, L. K. \& Komagata, K. (1997). Transfer of Bacillus alginolyticus, Bacillus chondroitinus,
Bacillus curdlanolyticus, Bacillus glucanolyticus, Bacillus kobensis, and Bacillus thaiminolyticus to the genus Paenibacillus and emended description of the genus Paenibacillus. Int J Syst Bacteriol 47, 289-298.

Takagi, H., Shida, O., Kadowaki, K., Komagata, K. \& Udaka, S. (1993). Characterization of Bacillus brevis with descriptions of Bacillus migulanus sp. nov., Bacillus choshinensis sp. nov., Bacillus parabrevis sp. nov., and Bacillus galactophilus sp. nov. Int J Syst Bacteriol 43, 221231.

Tamaoka, J. \& Komagata, K. (1984). Determination of DNA base composition by reversed-phase high performance liquid chromatography. FEMS Microbiol Lett 25, 125-128.

Thompson, J. D., Gibson, T. J., Plewniak, K., Jeanmougin, F. \& Higgins, D. G. (1997). The CLUSTAL_X Windows interface: flexible strategies for multiple sequence alignments aided by quality analysis tools. Nucleic Acids Res 25, 4876-4882.

Tindall, B. J. (1990a). A comparative study of the lipid composition of Halobacterium saccharovorum from various sources. Syst Appl Microbiol 13, 128-130.

Tindall, B. J. (1990b). Lipid composition of Halobacterium lacusprofundi. FEMS Microbiol Lett 66, 199-202.

Versalovic, M., Schneider, M., de Bruijn, F. J. \& Lupski, J. R. (1994). Genomic fingerprinting of bacteria using repetitive sequence-based polymerase chain reaction. Methods Mol Cell Biol 5, 25-40.

Yoon, J.-H., Kang, S.-S., Lee, K.-C., Kho, Y. H., Choi, S. H., Kang, K. H. \& Park, Y.-H. (2001). Bacillus jeotgali sp. nov., isolated from jeotgal, Korean traditional fermented seafood. Int J Syst Evol Microbiol 51, 1087-1092. 